\title{
David Oliver: Will robotic automation solve social care?
}

\author{
David Oliver consultant in geriatrics and acute general medicine
}

Berkshire

Ara Darzi, surgeon and former health minister, has this year called for "full automation" of "repetitive tasks" in health and care services.

In June the magazine National Health Executive quoted Darzi as saying that the NHS could free up $£ 12.5$ bn worth of staff time by investing in a "far reaching programme of automation." What further piqued my interest was the reported claim that a "further £6bn productivity gain" could be achieved in social care through automation.

Where had Darzi's quoted figures come from? The Institute for Public Policy Research (IPPR)—which describes itself as "the UK's leading progressive think tank"-published media releases about its report Better Health and Care for All: A 10 point plan for the 2020s, of which Darzi is a lead author. ${ }^{2}$ Section 2 of the report recommends full automation to fill staffing gaps and improve productivity.

The IPPR claims that robots can provide rehabilitation formerly given by trained human therapists or rehab assistants, encourage independence, deliver personal care, and reduce social isolation. In a table of estimated savings of time and money ${ }^{3}$ it makes the oddly precise claims that $24 \%$ of care workers' time, $25 \%$ of occupational therapists' time, and 29\% of registered nurses' time in social care settings can be saved, and it estimates the millions of pounds saved.

It shows no workings or figures, no appendices to explain how these extraordinary efficiencies were calculated. To support these claims the IPPR cites the 2017 Robotics in Social Care report by an interested party, the UK Robotics and Autonomous Systems (UK-RAS) Network. ${ }^{4}$ This claims that home help robots will be able to help people to "get out of bed, to wash and dress, to eat and drink, and with mobility and social engagement" and will enable older people to live better, longer, more fulfilling lives and remain more connected to friends and family. Detailed empirical evidence remains equally elusive in this source report, which sets out many "research challenges," ${ }^{4}$ none of which concerns proving such claims.

Social isolation and loneliness are prevalent in older people precisely because of a lack of human contact

See for yourselves the national eligibility criteria and thresholds for receiving statutory social services, and look at the people currently receiving them: many of these citizens are extremely frail, often with severe dementia and multiple dependencies. ${ }^{56}$

Read independent reports on the falling number of people now receiving social care-even those with "substantial" or "moderate" needs ${ }^{78}$ — and the stark lack of support for their unpaid carers (usually family). ${ }^{9}$ Look at the detailed mapping in NHS Benchmarking's national intermediate care audit on capacity, staffing and responsiveness, cost outcomes, and experiences of rehabilitation and reablement at home. ${ }^{10}$

Look at what the literature says on the alarming prevalence of social isolation and loneliness among older people precisely because of a lack of human contact. ${ }^{11}$ Examine credible modelling projections of unavoidable increases in the numbers of people with dementia, multimorbidity, frailty, and dependence. ${ }^{12}$ Then ask yourself how credible and well evidenced UK-RAS's and IPPR's data-lite assertions and assumptions are and whether automation will be the silver bullet its evangelists claim.

The current overclaiming about technology seems to be a solution in search of a problem, driven by industry lobbying, marketing, the financial bottom line, and passive acceptance of workforce gaps. We should never forget that health and social care is a people business and that those people might prefer more, not less, human contact.

Competing interests: See www.bmj.com/about-bmj/freelance-contributors/davidoliver

Provenance and peer review: Commissioned; not externally peer reviewed.

1 Lord Darzi calls for "full automation" strategy for repetitive health and care tasks. National Health Executive 11 June 2018. www.nationalhealthexecutive.com/Health-Care-News/ lord-darzi-calls-for-full-automation-strategy-for-repetitive-health-and-care-tasks.

2 Darzi A, Quilter-Pinner H, Kibasi T. Better health and care for all: a 10-point plan for the 2020s. Institute for Public Policy Research. 15 June 2018. https://www.ippr.org/research/ publications/better-health-and-care-for-all.

3 Kibasi T, Quilter-Pinner H. Embrace "full automation" to release "time to care" in the NHS and social care, says top surgeon, Lord Darzi. Institute for Public Policy Research. 11 June 2018. https://www.ippr.org/news-and-media/press-releases/embrace-full-automationto-release-time-to-care-in-the-nhs-and-social-care-says-top-surgeon-lord-darzi.

4 UK Robotics and Autonomous Systems Network. Robotics in social care: a connected care ecosystem for independent living. 2017. https://www.housinglin.org.uk/_assets/ Resources/Housing/OtherOrganisation/UK_RAS_robitics-in-care-report.pdf.

5 Social Care Institute for Excellence. Eligibility criteria for adults with care and support needs under the Care Act 2014. 2015. https://bit.ly/2Tp4SQf.

6 King's Fund. Illustrated summary of the Barker Commission's final report. 2014. https:// bit.ly/2DMP70G

7 King's Fund. Social care for older people: home truths. 15 Sept 2016. https://www. kingsfund.org.uk/publications/social-care-older-people. 
8 Richmond Group of Charities. Real lives. Sept 2016. https://richmondgroupofcharities. org.uk/sites/default/files/lr 5285 the richmond group social care real lives report.pdf. Carers UK. State of caring 2018. July 2018. www.carersuk.org/images/Downloads/ SoC2018/State-of-Caring-report-2018.pdf.

10 NHS Benchmarking Network. NAIC key resources. https://www.nhsbenchmarking.nhs. uk/naic-resources-key-documents.

11 Coyle CE, Dugan E. Social isolation, loneliness and health among older adults. J Aging Health 2012;24:1346-63. 10.1177/0898264312460275. https://journals.sagepub.com/doi/ abs/10.1177/0898264312460275?journalCode=jaha. 23006425
12 Kingston A, Robinson L, Booth H, Knapp M, Jagger CMODEM project. Projections of multi-morbidity in the older population in England to 2035: estimates from the Population Ageing and Care Simulation (PACSim) model. Age Ageing 2018;47:374-80. https://

academic.oup.com/ageing/article/47/3/374/4815738. 10.1093/ageing/afx201 29370339

Published by the BMJ Publishing Group Limited. For permission to use (where not already granted under a licence) please go to http://group.bmj.com/group/rights-licensing/ permissions 